\title{
Non-Target Indicator
}

National Cancer Institute

\section{Source}

National Cancer Institute. Non-Target Indicator. NCI Thesaurus. Code C161483.

An indication as to whether a non-target tumor, lesion, or site of disease is present. 